\section{Confused ethics of blood testing}

Willi. the publication this month of the results of compulsory blood tests for the acquired immune deficiency syndrome (AIDS) virus in potential military recruits in the United States has provided valuable, and to some extent disturbing, information on, the spread of the virus, monitoring attempts in Britain are foundering on ethical and bureacratic rocks.

According to Sir Richard Doll, who has been asked by the British Medical Research Council to try to overeome the problems, all concerned are agreed that it would be unethical to take blood specifically for AIDS testing without informing those being tested of the purpose and result of the test. But the contentious question is whether the testing of blood samples taken for completely different purposes should be allowed.

Those who argue against such tests do so on the grounds that it would be unethical not to pass on the result of positive tests to the individuals concerned and yet unethical also to inform them because of the lack of prior consent. Those for whom the need to monitor the spread of the virus is paramount advocate that tests are carricd out in an anonymous way so that it would be literally impossible to identify the individual that provided the blood sample. The justification for brushing the ethical problem under the carpet is that without information on the spread of the virus, it will be hard to persuade those at risk. including politicians, of the need for preventive measures.

As sexual transmission is the only way by which the virus can spreald in the general population, it is necessary only to monitor blood samples from sexually active groups. One obvious source of such samples for anonymous testing would be antenatal clinics, but the Royal college of Obstetricians and Gynaceologists has objected to the idea. Another source being investigated is sexually-transmitted disease clinics, which have the advantage of including both sexes.

At present. the compulsory tests on potential blood donors provide the only source of information on the spread of the AIDS virus in the British population at large. Among 140.000 potential new donors tested between February and May this year, 7 individuals (or 0.05 per thousand) had a positive test. From October 1985. when the testing began. until May 1986. the rate wats 0.02 per thousand but it is impossible to determine the rate per donor, according to Dr Harold Gunson. who collates the figures. because a substantial but unknown number of donors have given blood on more than one occasion during that period.

Prevalence among new donors is the best figure to monitor for a trend but none is yet discernible, says Gunson, who is in the process of determining the sex and age distribution of the donor pool so that prevalences can also be worked out on that basis. The overall prevalence among UK blood donors is about 20 -fold less than it was in August 1985 in the United States, the latest period for which figures are available.

The UK Ministry of Defence is opposed to the compulsory testing of potential military recruits. But in the United States that source has provided valuable figures on the prevalence of the virus in a sexually active heterosexual population.

Figures published in the 4 July Morbidity and Mortality Weekly Report show that the overall prevalence from October

\section{Tokyo}

JAPAN'S Liberal Democratic Party (LDP) won a landslide victory throughout Japan in the double election on 6 July, except in Miyakcjima, a tiny Pacitic Island south of Tokyo. where the party suffered a crushing setback. Local and worldwide opposition from environmentalists to goyernment plans to build a US military airficld on the island probably helped to sway the voters.

Miyakejima is an idyllic volcanic isle blessed with coral reefs. luxuriant tropical vegetation and two rare endemic species of bird. the Izu Island thrush (Turdus celaenops) and ljima's willow warbler (Phylloscops ijimae). But if military planners have their way. the island will beconce an "aircratt carrier" for US Navy warplanes to practice night landing.

The local islanders, however, have put up dogged resistance to the government's plan. All attempts by the Defense Agency to hold public hearings on the issue have failed and two island assemblymen have been threatened with recall for failing to voice their opposition to the airfield. In the general election the Japan Socialist Party won easily over LDP with a vote double that of the previous election. International support for the islanders causc has grown rapidly and they can now count British royalty amongst their allies.

In late May, the Wild Bird Society of Japan reported that the Duke of Edinburgh. president of the World Wilditife Fund, had written to Prime Minister Yasuhiro Nakasone and the US Department of Defense appealing for the plan to be called off to protect wildlife in the island. Following this the International Council for Bird Preservation passed a
1985 to March 1986 was 1.4 per thousand. Figures varied widely by region and age group, ranging from 0.2 to 10.1 per thousand. The latter figure was for those of 26 or more in the central states on the Atlantic seaboard. At last month's huge AIDS conference in Paris, a figure of 20 per thousand was given for $18-25$ year old recruits from Manhattan. Just over 300.000 potential recruits have been tested overall. with 459 positive results. The prevalence rate in males was three times that of females.

Seropositive applicants are excluded from military service, illustrating the growing discrimination that discourages people from agreeing to be tested and physicians from the prospect of having to inform anyone who has not specifically agreed to be tested of a positive result. Exclusion from life insurance and the possibility of losing one's job are added discouragements.

Peter Newmark

\title{
Islanders put environment first
}

resolution in June opposing the airficld's construction.

The Environment Agency carried out a survey in the area of the planned construction after a volcanic cruption in 1983 and concluded that "artificial objects would destroy the area if put up in defiance with harmony of the scenery". But the agency has yet to clarify its official position.

Numerous LDP delegations have visited the island to try and woo the islanders with promises of investment. But to no avail. As one islander put it: "important people from the LDP say they will make the island a "mountain of treasure' but the island is already a mountain of treasures".

David Swinbanks

\section{More dead penguins}

THE mysterious mortality of rockhopper and gentoo penguins observed in the Falkland Islands (see Nature 322, 4; 1986) has now spread to Argentina. But the Argentine National Atomic Energy Commission (CNEA) has ruled out the possibility, suggested at a press conference at the Soviet Embassy in Buenos Aires, that radioactivity is involved. According to the Soviets, the four British ships sunk during the $\mathbf{1 9 8 2}$ Falklands conflict had been carrying nuclear weapons, the casings of which had leaked, contaminating the waters. The CNEA scientists, however, are preserving a proper academic detachment on the issue. Asked to comment on the deaths of some 300 penguins near Piero Deseado, they stated categorically that, even if some radioactive material had escaped into the sea, the concentration would have been far too low to be dangurous. Vera Rich 